Pp.129 -142

\title{
Qur'anic Allusions in Naguib Mahfouz's Midaq Alley: Comparing Two Arabic-English Translations
}

\author{
Najlaa R. Aldeeb \\ Language Center, Batterjee Medical College \\ Jeddah, Saudi Arabia
}

\begin{abstract}
The Holy Quran is a crucial text in the Arabic culture, and hence the Arabic literature uses it extensively. As a hypertext, the Quran transcends its function in the Arabic culture, and Qur'anic verses and phrases serve in literary works as pieces of advice and expressions of wisdom. This paper aims to compare the two English translations of Naguib Mahfouz's Midaq Alley (1947), by Trevor Le Gassick (1966), and Humphery Davies (2011). The paper examines the rendition of allusions to Quran and explores the strategies deployed by the translators. The language used in the source text reflects the culture in which it is born and determines the ideologies of its users. Before Mahfouz won the Noble Prize in 1988, the Westerners were prejudiced "against Arabs and Islam," and they considered Arabic literature as embargoed (Said, September 17, 1999). The paper hypothesizes that the purpose of the two translations of Midaq Alley is to transfer the Egyptian culture to the target reader (TR). The underpinning approach is skopos theory, whose principles are: skopos, coherence, and loyalty (Nord, 2018). The paper queries how loyal each translator is to the ST and ST author to achieve functional adequacy. One finding shows that Le Gassick renders the Quranic allusions literally ignoring the SC; however, Davies either uses cultural equivalents or resorts to paraphrasing, reducing the image to its sense. Second, the new translation of Davies transfers the Qur'anic culture-specific images feasibly. Finally, not recognizing the pictures and their functions in the ST affects their interpretations negatively.
\end{abstract}

Keywords: comparative translation, intertextual coherence, intratextual coherence, Qur'anic allusions, Skopos theory

Cite as: Aldeeb, N.R. (2020). Qur'anic Allusions in Naguib Mahfouz's Midaq Alley: Comparing Two Arabic-English Translations. Arab World English Journal for Translation \& Literary Studies 4 (2) 129 -142. DOI: http://dx.doi.org/10.24093/awejtls/vol4no2.10 


\section{Introduction}

When Le Gassick first translated Mahfouz's Midaq Alley in 1966, Arabic literature was neither known nor read in the West. According to Said (September 17, 1999), Westerners consider Arabic as "a controversial language.... disrespectable and consequently dangerous [and] unapproachable." Americans and Europeans did not care to explore worth-reading Arab writers because Arabic literature "was ignored, distorted or marginalized in the West," and they translated a limited number of Arabic books. Even these translations were terrible (Altoma, 2005, pp. 1215). Only after Mahfouz had won the Nobel Prize in 1988, did the situation change and the West translated a myriad of Arabic novels accurately reflecting the cultures and ideologies of their producers.

Mahfouz's Midaq Alley comprises allusions to the Quran, used as a part of the Egyptian culture. This inclusion confirms the idea that the Arabic literature considers the Quran as a hypertext because it is linked to other texts. According to Jaffer and Jaffer (2009), the Quran is "the mother book" (umm al-kitāb), "the guide" (huda), and "the wisdom" (hikmah) (pp. 11-15). It identifies earlier divine books, offers historical events, emphasizes morals, and provides guidance and laws for humans. Therefore, it transcends its religious function in the Arabic culture, and novelists use qur'anic verses as pieces of advice.

Affected by the Quran and its figurative devices as a part of his culture, Mahfouz uses Qur'anic verses as phrases of wisdom to depict his characters in Midaq Alley. Translating these allusions is controversial because of their symbolic use. Qur'anic verses must be explained by a Muslim using "quotation marks or some graphic markers" to point out their "uniquely contextsensitive sense" (Baker and Saldanha, 2009, p. 226). However, other scholars state that it is permissible for non-Arabs to express the meaning of Qur'anic words in their languages as a form of exegesis, or at least understanding of the text (Picktall, 1931, p. 442). Although the style and strategies of translating the Quran differ, the form has to be similar to the Arabic text in terms of Surah *and Ayah**

Comparing the two translations of Mahfouz's Midaq Alley helps identify, first, the problems that might have encountered the translators when they rendered the religious allusions in the ST. Second, it serves in a better understanding of the different strategies applied to translate Mahfouz's style. Mahfouz uses phrases from the Quran to indirectly educate the readers and stir their emotions. Writers conceal their attitudes towards the content of their texts and use personal styles in characterization (Armstrong and Federici, 2006). Mahfouz's idiosyncratic timeless style marks out different voices in Midaq Alley, and his use of religious allusions fulfills an aesthetic rather than an informational function.

This paper investigates how Le Gassick and Davies mediate Mahfouz's distinctive style via their own inadvertently signaled stylistic space-time, through their deliberate stylistic choices. It illustrates how religious allusions, functioning as pieces of wisdom in the Egyptian culture, may lose their meaning if not recognized in translation. The paper explores the concept of culturespecific images in the Quran in two sections: images with literal use and images with metaphorical use. Consequently, the paper compares the two English translations of Mahfouz's Midaq Alley, 
and applies the skopos theory to determine the strategies used in translating literal and figurative religious allusions and the styles of the two translations.

\section{Mahfouz's Language and Style in Midaq Alley}

Language and culture are inseparable, so the language used by Mahfouz in Midaq Alley reflects his culture, ideologies, and style of writing. Barthes (2009) compares cultural events in literary works to myths. He suggests viewing literary works, such as novels, on a mythical level to recognize the symbolic meaning of the stories along with the original particulars of the narrative. Developing this idea, Moramollu (2017) argues that the term "myth" used by Barthes can function "as a synonym of ideology" (p.2), a systematic body of concepts about human life or culture.

Literature allows a specific work about a specific time and place to speak through its narrator and characters. However, in his paratext, the introduction of Mahfouz's Midaq Alley, Le Gassick (1966/ 1975) argues that the novel is ageless as its events, themes, and "the universal problems of behavior and morality ... are restricted neither to time nor place" (p. 8). Mahfouz employs three main elements that characterize his unique style in Midaq Alley: omniscient narrator, dialogues, and religious allusions.

Mahfouz deploys an impersonal narrator to tell the stories of the inhabitants of the Alley simply and smoothly. The novel has no protagonist, and the omniscient narrator reveals the characters' thoughts. The dissatisfaction of the characters is creatively conveyed by the narrator, particularly when the narration conflicts with what that characters say out loud. The narrator sides with the ones who do not want to leave the Alley. Still it does not show compassion for the unkind characters, like Zaita, the cripple-maker, and Hamida, a rebellious and strong-willed character, who becomes a prostitute. Another technique is the use of dialogues. In an interview about his translation and Naguib Mahfouz's writing, Davies (May 29, 2011) says that Midaq Alley Mahfouz deals with life in a straightforward manner by using dialogues in colloquial and classical Arabic. Mahfouz employs discussions as a device of narration to explore the themes and depict the various characters with their keen perception and great humor. Third, Midaq Alley is teemed with Qur'anic images, said by all characters from the most pious to the most corrupt. This technique shows how Islam shapes the lives of people in Egyptian culture.

Thus, among the features of Mahfouz's style are religious allusions from the Quran, which are common in Egyptian literature. Relying on the fact that people in the Arab world can easily recognize religious references in literary works, Mahfouz applies this device to guarantee that he sends his message successfully.

\section{The Skopos Theory}

Skopos theory has three principles: skopos, coherence, and loyalty. Skopos is a Greek word meaning "purpose"; in the skopos theory, "purpose" means the function of the translation. The task that translators want to achieve from their interpretations guide their decisions. Coherence in the skopos theory has two types: intratextual and intertextual. The former requires the interpretation to be coherent in itself and to make sense as a text. The latter necessitates coherence with the ST. Therefore, the translators of Midaq Alley should use equivalents that match the target reader (TR) culture and ideology. However, skopos/purpose is more critical 
than coherence in the skopos theory. Most importantly, in the skopos theory translators seek to find functional equivalents and cultural substitutes that serve in transferring the message of the ST to the TR.

The skopos theory is a combination of the two well-established approaches: semantic and communicative. This paper checks the "adequacy and acceptability" of the two translations of Midaq Alley and examines whether the translators apply "semantic [or] communicative equivalence" (Rushdy, 1997, p. 245). The semantic approach is biased to the ST, and the communicative approach is inclined to the TT. In contrast, the functional approach produces a target text that "carries" the purpose of the ST to the target reader and interprets the source culture (SC) phenomena (Vermeer, 1987, p. 29). Therefore, this paper applies a top-down model of analysis assuming that the purpose of the translation of Midaq Alley is to transfer the $\mathrm{SC}$ to the TR.

\section{Applying The Skopos Theory to Analyze the Translation of Qur'anic Allusions in Midaq Alley}

Applying the skopos theory, mainly Nord's model of text analysis necessitates analyzing the translations examining the purpose of the interpretations, their internal coherence, and their loyalty to the ST and SC.

First, the two translations involved are documentary since the St serves as a document of the SC communication between the author and the ST recipients. According to Reiss (1971/2000), the translation of a literary text such as a poem, novel, or play is expressive; it transmits both the aesthetic and artistic forms and the accurate meaning of the ST. Thus, since Midaq Alley is a socio-realistic novel, the translators should adopt the standpoint of the ST author (p. 58), and the style of the ST author should be a priority. Translators retain the culture-bound religious allusions from the ST to preserve "local color" (Nord, 2005, p. 81). The TTs are produced in English to acquaint the English speakers with the ST culture.

Translating the Qur'anic allusions in Midaq Alley is problematic. It needs skillful interpreters to transfer not only the explicit and intended meaning but also the elements of the SC. According to Altima, Arabic literary works are difficult for the West to understand. He describes the Arabic language as a "hurdle" (2005, p. 22), teemed with rhetorical images, while English has a highly abstract and formalized language system. Wong and Shen (1990) argue that the style and strategies applied in solving the problems that literary translators face when they translate cultural elements are affected by their time. Examining the translation of religious allusions in two TTs of Midaq Alley turned in two different periods sheds light on the strategies applied and the styles of two interpretations.

Based on Nord's model, the purpose of the translation determines the translation strategy and the function of the TT in the target culture (TC). Translating literary works loaded with culture-specific images requires specific strategies. Newmark (1988) suggests translation procedures to solve the problem of culture-specific items. These strategies are transference, neutralization, equivalence, componential analysis, synonymy, literal translation, label, naturalization, modulation, recognized translation, compensation, paraphrase, couplet, and 
notes. Also, $\mathrm{Ku}$ (2006) recommends strategies moving from source-oriented to readeroriented. Ku's strategies are borrowing, literal translation, equivalence, reduction and omission, description, explicitation and amplification, and cultural adaptation. To overcome the problem of aesthetic differences, Baker (1992/2006) suggests using (1) idioms of similar meaning and form, (2) expressions of the same meaning but different structure, (3) paraphrasing, or (4) omission. Thus, the paper examines the properness of the strategies applied by the two translators of Midaq Alley by assessing the translators' competence in transferring the SC to the TT.

First, the paper spots the Quranic verses and phrases that have literal connotations and the culture-specific images that have figurative implications. Second, it compares the TTs to the ST and to each other to investigate the feasibility of the translations. Third, the paper determines the effectiveness of the intratextual and intertextual coherence in the translations.

\section{a. Religious Allusions with Literal Meaning}

The first purpose of Qur'anic references in Midaq Alley is to serve as a device of narration to provide a consistent ideological framework. Leppihalm (1997, p. 44) states that allusions can function as an aid of characterization. Mahfouz uses verses and phrases from the Quran to economically introduce the characters. The extract below shows how the narrator alludes to the Quran in depicting El-Husseini as a religious character, adamant to do good deeds daily; otherwise, he is "sorrowing and reproaching himself." The paper assesses if the TTs maximize the significance of the cultural situation.

\section{Table 1. Depicting Radwan el-Husseini}

\begin{tabular}{|c|c|c|c|c|}
\hline الشخصية & 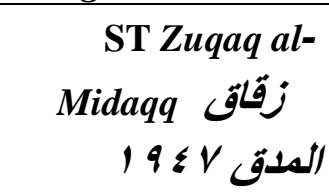 & الآية القر آنية & $\begin{array}{l}\text { TT1 Midaq Alley } \\
\text { translated by Le } \\
\text { Gassick } 1966\end{array}$ & $\begin{array}{l}\text { TT2 Midaq Alley } \\
\text { translated by Davies } \\
2011\end{array}$ \\
\hline (بصف السيد & 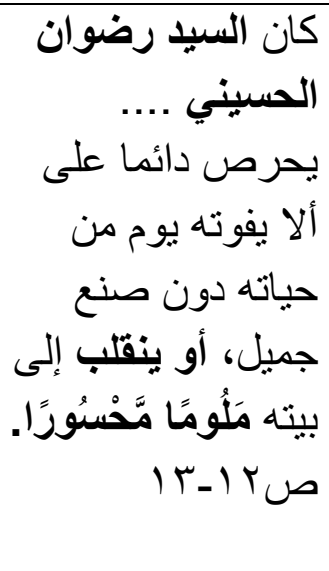 & 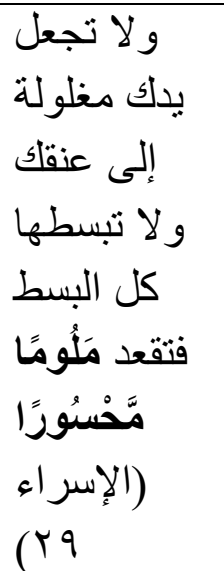 & $\begin{array}{l}\text { Radwan Husaini .... } \\
\text { had always taken care } \\
\text { that not a single day } \\
\text { should pass without } \\
\text { doing some good } \\
\text { deed or receiving in } \\
\text { his home some } \\
\text { abused or } \\
\text { unfortunate person. } \\
\text { (p. 17-18). }\end{array}$ & $\begin{array}{l}\text { It was Master } \\
\text { Radwan's constant } \\
\text { preoccupation not to } \\
\text { allow a day to pass } \\
\text { without performing } \\
\text { some act of kindness, } \\
\text { and if he did not do so, } \\
\text { he would return to his } \\
\text { house sorrowing and } \\
\text { reproaching himself } \\
\text { (p. 7). }\end{array}$ \\
\hline
\end{tabular}

Since the purpose of the translation is to transfer the situation, culture, and ideologies of the ST to the TR, the transference of Qur'anic references are compared to their English interpretations by Al-Hilâlî and Khân (1996). Both translators do not recognize that the phrase 
ملوما محسورا is from the Quran. The presupposition in the ST is that the reader realizes them, and in the TC, these allusions are unknown. TT1 violates intertextual coherence since the meaning does not correspond to that in the ST. However, it achieves intratextual consistency. TT2 performed both types of integration along with the culture as the meaning of the situation is transferred. It keeps fidelity to the ST in order not to violate Grice's maxims of quantity, quality, relation, and manner. TT1 ignores the factor of intertextual coherence, giving a meaning not intended in the ST, and violating the relation maxim.

The verb alludes to verse 9, surat Al-Inshiqâq; it means "return," and the phrase متَلُومًا مَنَحْنُورًا "regret." The complete meaning is that El-Husseini would return home blaming himself and regretting if he did not perform "some act of kindness." Although both translators do not recognize the Qur'anic phrase, Davies in TT2 renders it more properly by paraphrasing the meaning of the words. Thus, the new translation provides the intended purpose, while Le Gassick in TT1 mistranslates the reference to the Quran, changing the meaning and violating the axiom of coherence.

Translation loss may occur when translating literary works, and this loss increases on the metaphorical level. In Midaq Alley, the difference between Arabic, the language of revelation, and English, the TL, may cause translation loss. The example below shows an extended metaphor as the image extends over two verses and has different elements. El-Hussaini is not an expert with in-depth knowledge of Islam; however, he is a sincere believer and righteous man.

Table 2. Translating the Figurative Meaning of ولي , One of Allah's Names

\begin{tabular}{|c|c|c|c|c|}
\hline الراوي & 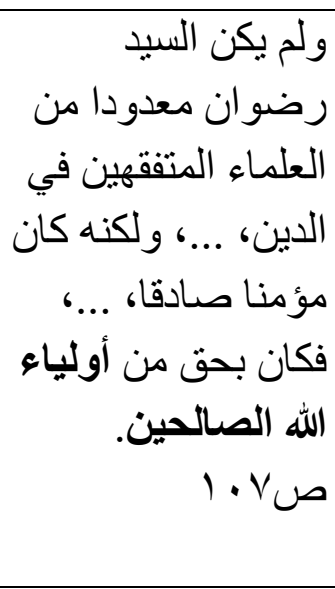 & 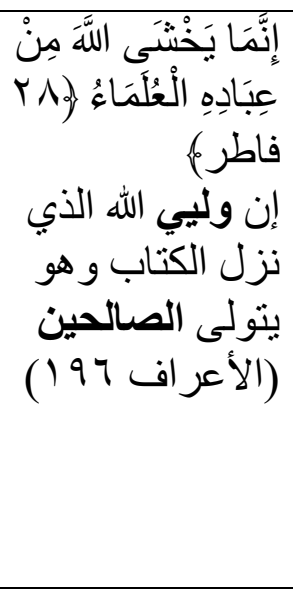 & $\begin{array}{l}\text { Radwan Husaini } \\
\text { was not a scholar } \\
\text { claiming to know } \\
\text { all about holy law } \\
\text { and Islam.... He } \\
\text { was merely a } \\
\text { sincere believer, } \\
\text {... All agreed he } \\
\text { was truly a saintly } \\
\text { man of God. (p. } \\
\text { 100) }\end{array}$ & $\begin{array}{l}\text { Master Radwan was } \\
\text { not considered a } \\
\text { scholar with a deep } \\
\text { knowledge of the } \\
\text { technicalities of } \\
\text { religion .... He was, } \\
\text { however, a sincere } \\
\text { believer, ..., and } \\
\text { could thus, in truth, be } \\
\text { considered one of } \\
\text { God's Righteous } \\
\text { Friends. (p. } 84 \text { ) }\end{array}$ \\
\hline
\end{tabular}

The genre of the ST is a novel, and the TTs should be the same, so the translators should produce aesthetic TTs, creatively written to fulfill the same appellative function. The two translators have similarities and differences in translating this excerpt. The axiomatic theory the skopos theory ignores syntactic and semantic features. However, it is significant to mention that Le Gassick uses "Islam" as an equivalent to الاين. He is biased to the ST, and he changes the passive voice of معدودا using the present participle "claiming" as an action done by El-Husseini. Le Gassick also uses the word "merely" as a substitute to كن .Adding the sentence "All agreed" is an addition that affects the adequacy of TT1. Also, using the noun phrase "saintly man" reflects the lack of 
consistency of intratextual coherence, moving between Islam and Christianity; however, it suits the background and culture of the TR.

In the same extract, Davies adds the word "thus" for intratextual coherence. Both translators agree on "sincere believer" for مؤمناصادقا but but adopt the target culture when translating to overcome the wide gap in cultural norms between the ST and TR. The etymology of the word وني أولياء, one of Allah's names which means literally "the guardian who manages everything and disposes of all affairs." Since Allah "loves the believers and provides them with special help and support" (Assyyid, 2014, p. 79), the literal meaning is "supporter," as Surat Ash-Shooraa says in Ayah 28 and Al-A'râf, 196. The symbolic sense of the phrase is "a righteous man" who supports people. Le Gassick renders it as "a saintly man of God," and Davies says "one of God's Righteous Friends." Both translations take into account the nature of the TC; they use equivalents effective in Christianity, the supposed religion of the TR. Thus, Davies' adaptation is more acceptable than Le Gassick as it keeps the consistency of intratextual coherence.

Another purpose of uttering verses from the Quran is for the narrator to evoke many emotions and ideas. Lennon (2004) argues that allusion attracts reader attention. In the extract below, the integration between the description of the narrator and the character's words shows the ugliness of "Boss Kersha," who uses verses from the Quran to justify his abnormal actions and validate what God has forbidden. The allusions to the Quran taps into the reader's body of thought and magnify the social contradictions in the Egyptian culture. Unlike El-Husseini, Kersha is often entangled in scandals, unable to control his desires. He is a drug dealer and a seducer of young boys.

Table 3. Translating a Religious Allusion with a Literal Meaning in the Quran, but Figurative meaning in the Egyptian Culture

\begin{tabular}{|c|c|c|c|c|}
\hline الثخصية & 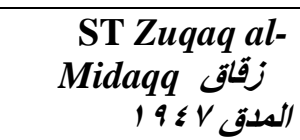 & الآية القر آنية & $\begin{array}{l}\text { TT1 Midaq Alley } \\
\text { translated by Le } \\
\text { Gassick } 1966\end{array}$ & $\begin{array}{l}\text { TT2 Midaq Alley } \\
\text { translated by Davies } \\
2011\end{array}$ \\
\hline الراوي & 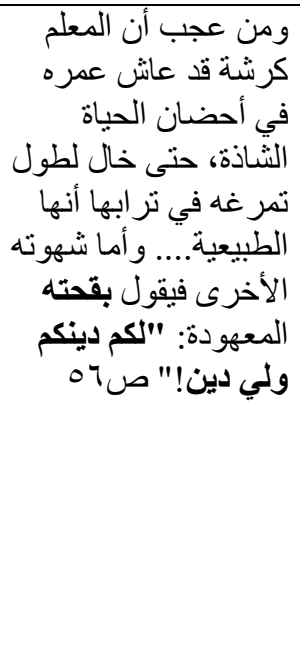 & لكم دين (الكافرون ولي & $\begin{array}{l}\text { Strange as it seems, } \\
\text { Mr. Kirsha had } \\
\text { always lived a most } \\
\text { irregular life, and he } \\
\text { had rolled in its dirt } \\
\text { so long that it } \\
\text { appeared to him a } \\
\text { perfectly normal } \\
\text { one.... Concerning } \\
\text { his "other vice," he } \\
\text { would say in his } \\
\text { customary way: } \\
\text { "You have your } \\
\text { religion, I have } \\
\text { mine!" (p. 55-56) }\end{array}$ & $\begin{array}{l}\text { The strange thing is } \\
\text { that Boss Kersha had } \\
\text { always lived a life of } \\
\text { deviancy and had } \\
\text { come, from long } \\
\text { familiarity to think of } \\
\text { it as normal.... Where } \\
\text { his other appetite was } \\
\text { concerned, he said, } \\
\text { with his familiar } \\
\text { cough, quoting the } \\
\text { Qur'an, "You have } \\
\text { your religion and I } \\
\text { have mine"! (pp. 42- } \\
\text { 43) }\end{array}$ \\
\hline
\end{tabular}

Arab World English Journal for Translation \& Literary Studies 
The paper analyzes the whole extract starting with the translation of the proper noun and title to pinpoint the style and strategies of each translator. In TT1, giving the character the title "Mr.," a title given to educated people, conceals an essential element of culture-specific items. The English synonym of the title could be "master" or "craftsman"; however, the word "boss" used in TT2 is better than "Mr." Aïcha Ait Cherif et al. (2011) state that names are letters and sounds; most consonants in English have the same sounds in Arabic. They are transliterated, written in the Arabic alphabet, to transfer the SC to the TR since these names reflect the original culture of the story. Similarly, the transliteration of Arabic names to English is common. TT2 gives a more appropriate translation of the proper nouns كرشة than TT1 because it reflects the way the Egyptian people pronounce the name "Kersha."

Kersha is indulgent in his lusts and knows no limits; he neither regrets nor expresses remorse for his wrong deeds. By saying شهوته الأخرى, the narrator alludes to homosexuality. Mahfouz reveals homosexuality in a euphemistic manner as it is the way in the SC. This style appears in TT2 by using the equivalent "his other appetite," but TT1 reveals it by saying the "other vice." TT2 is more coherent to the SC, which hides this obscene practice and avoid disclosing it.

To normalize his abnormal behavior, Kersha uses religious allusion as a device to play on the reader's emotions. Although the verseلكم دينكم ولي دين is meant literally in the Holy Quran, it is currently used in the Arabic language to give a figurative meaning: "leave me alone" or "Don't stick your nose into my business." The way Kersha speaks gives him a social identity, and it indicates his social group. TT2 translator introduces the verse saying it is from the Quran and writes it in italic, which confirms his recognition of the allusion. He renders it literally for the faithfulness to the ST to convey one of the features of the Egyptian culture. However, TT1 translates it literally without an introduction to the verse of the Quran, which violates the communication function of the TT.

Far from noticing the religious allusion, both translators fail to render the word قحته, which means "his rudeness." The etymology of قحة indicates that it is a culture-specific image derived from قق "which refers to "boldness" in the Arabic culture. Translator 1 renders it as a "way," while translator 2 transfers it as a "cough" which is كحة in Arabic. Not knowing the meaning of the word قحتنه the two translators make a mistake that affects the transference of the Egyptian culture. This error prevents them from emphasizing how rude people like Kersha are, so it does not help in revealing Kersha's hedonistic nature and impudence.

\section{b. Religious Allusions with figurative Meaning}

Recognizing the religious allusions is not enough for the translator to transfer the intended meaning of the culture-specific images to the TR. Both translators recognize The Qur'anic verse in the extract below as they put it between quotation marks although they do not give it an introduction. Le Gassick puts part of the phrase between quotation marks, rendering it literally, while it is used figuratively in the Quran and the novel. 
AWEJ for Translation \& Literary Studies Volume, 4 Number 2 May 2020

Qur'anic Allusions in Naguib Mahfouz's Midaq Alley

Aldeeb

Table 4. Translating Religious Allusion with a Figurative Meaning in the Quran and Egyptian Culture

\begin{tabular}{|c|c|c|c|c|}
\hline الر اوي & 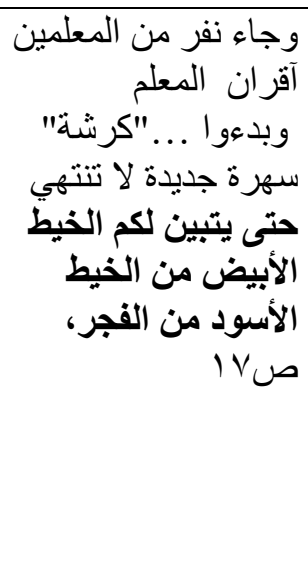 & 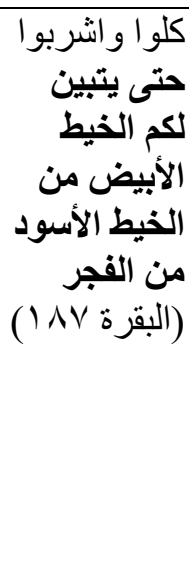 & $\begin{array}{l}\text { Then another group } \\
\text { of men arrived, all } \\
\text { peers of the café } \\
\text { owner Kirsha .... } \\
\text { There they started a } \\
\text { small party which } \\
\text { would not end until } \\
\text { the dawn gave } \\
\text { enough light to } \\
\text { distinguish "a } \\
\text { black from a white } \\
\text { thread" (p. 21) }\end{array}$ & $\begin{array}{l}\text { A band of Kersha's } \\
\text { peers then arrived ... } \\
\text { a second get- } \\
\text { together began that } \\
\text { would not come to } \\
\text { an end "until the } \\
\text { white thread of } \\
\text { dawn could be } \\
\text { distinguished from } \\
\text { the black thread of } \\
\text { night" (p. 11). }\end{array}$ \\
\hline
\end{tabular}

Muslims who fast Ramadan know the culture specificity of the image of "dawn". Verse 187, Surat Al-Baqarah, instructs Muslims to eat and drink until they distinguish the light of dawn from the darkness of dusk. Muslims understand the Qur'anic culture-specific image and get the implied meaning. The ST reader knows that Kersha and his peers stay "until the following day" or "until sunrise." Translating the image literally in TT1 does not achieve the intratextual coherence as it does not make "sense within the communicative situation and culture, in which it is received." (Nord, 1997, p. 108) Thus, TT2 will be more comprehended by the TR; Davies gives more explanation showing the intended meaning.

In addition to the literal translation, the translator of the TT1 violates the grammatical use of articles. The definite article "the" should be used instead of the indefinite "a." Also, Le Gassick violates the rule of translating the Quran when he does not keep the form of the verse paralleled to the original text. Unlike Davies in TT2, Le Gassick puts inverted commas around the noun phrase "a black from a white thread," excluding the verb from the quote.

The third function of religious allusions in Midaq Alley is to educate and preach the reader. The following table shows the transference of verses and phrases from the Quran, whose gist is a piece of advice. El-Husseini is giving admonition and guidance:

Table 5. Translating Religious Allusion Functioning as Pieces of Wisdom

\begin{tabular}{|c|c|c|c|c|c|}
\hline Extract No & الثخصية & $\begin{array}{c}\text { ST Zuqaq al- } \\
\text { Midaqq } \\
\text { الملق زقاق } 19 \text { VV }\end{array}$ & الآية القر آنية & \begin{tabular}{l}
\multicolumn{1}{c}{ TT1 Midaq } \\
\multicolumn{1}{c}{ Alley } \\
translated by Le \\
Gassick 1966
\end{tabular} & $\begin{array}{l}\text { TT2 Midaq Alley } \\
\text { translated by } \\
\text { Davies } 2011\end{array}$ \\
\hline 1 & السيا رضوان & 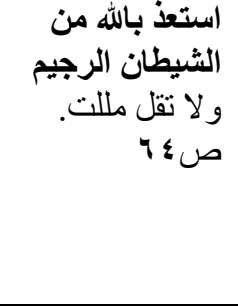 & و وذريتها من أعنانها & $\begin{array}{l}\text { ".... seek refuge } \\
\text { from the devil in } \\
\text { God and never } \\
\text { say you are } \\
\text { bored ..." (p. } \\
62)\end{array}$ & $\begin{array}{l}\text { "... I seek refuge } \\
\text { with God from } \\
\text { Lapidated Satan- } \\
\text { say not that you } \\
\text { have grown weary } \\
\text { of this world!" (p. } \\
48 \text { ) }\end{array}$ \\
\hline
\end{tabular}

Arab World English Journal for Translation \& Literary Studies

ISSN: 2550-1542 | www.awej-tls.org 
AWEJ for Translation \& Literary Studies Volume, 4 Number 2 May 2020

Qur'anic Allusions in Naguib Mahfouz's Midaq Alley

Aldeeb

\begin{tabular}{|c|c|c|c|c|c|}
\hline 2 & السيد رضوان & 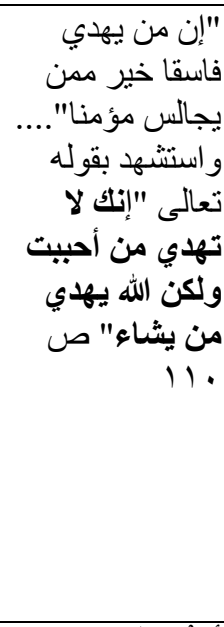 & أنكبت لا تهني من الله & $\begin{array}{l}\text { "He who reforms } \\
\text { a profligate does } \\
\text { better than he } \\
\text { who sits with a } \\
\text { believer." He ... } \\
\text { recited the verse } \\
\text { from the Koran: } \\
\text { "You cannot } \\
\text { lead aright } \\
\text { whomever you } \\
\text { wish; it is God } \\
\text { who leads } \\
\text { whomever He } \\
\text { wishes" (p. 103). }\end{array}$ & $\begin{array}{l}\text { "It is better to bring } \\
\text { a sinner to } \\
\text { guidance than to } \\
\text { keep company with } \\
\text { a believer." He ... } \\
\text { quoted to himself } \\
\text { the Almighty's } \\
\text { words, "Thou will } \\
\text { not be able to } \\
\text { guide everyone } \\
\text { whom thou lovest; } \\
\text { but God guides } \\
\text { those whom He } \\
\text { will," (p. 87) }\end{array}$ \\
\hline 3 & السيد رضوان الحسيني & 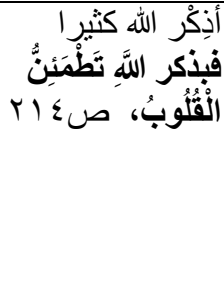 & 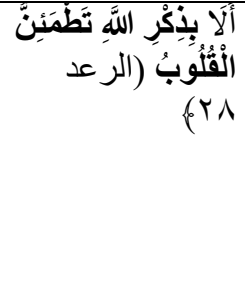 & $\begin{array}{l}\text { "...Remember } \\
\text { God often, for it } \\
\text { is by doing so } \\
\text { that our hearts } \\
\text { learn } \\
\text { contentment...." } \\
\text { (p. 189). }\end{array}$ & $\begin{array}{l}\text { "Repeat God's } \\
\text { name often, for 'in } \\
\text { the mention of His } \\
\text { name the heart } \\
\text { finds peace' ( } \mathrm{p} . \\
169) \text {. }\end{array}$ \\
\hline 4 & السيد رضوان & 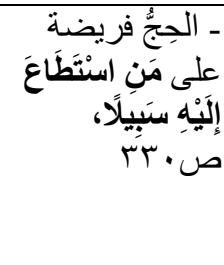 & 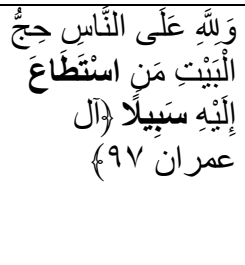 & $\begin{array}{l}\text { "The pilgrimage } \\
\text { is a duty for all } \\
\text { who can make } \\
\text { it...." (p. 281). }\end{array}$ & $\begin{array}{l}\text { "To make the } \\
\text { pilgrimage is a } \\
\text { sacred duty } \\
\text { incumbent on any } \\
\text { who has the } \\
\text { means," (p. 263). }\end{array}$ \\
\hline 5 & السيد رضوان & 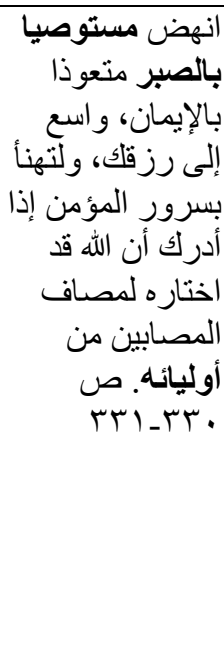 & 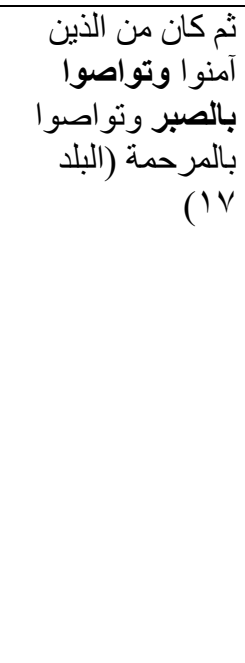 & $\begin{array}{l}\text { “.... Go on, put } \\
\text { your trust in } \\
\text { patience and } \\
\text { faith. Earn as } \\
\text { much as possible } \\
\text { and be as happy } \\
\text { as a pious man } \\
\text { convinced that } \\
\text { God has chosen } \\
\text { him to help those } \\
\text { in need." P. } 280\end{array}$ & $\begin{array}{l}\text { "... Arise, making } \\
\text { it your business to } \\
\text { be patient and } \\
\text { taking refuge in } \\
\text { faith, and seek your } \\
\text { daily bread, and } \\
\text { savor the happiness } \\
\text { of the believer as } \\
\text { he realizes that } \\
\text { God has chosen } \\
\text { him to join the } \\
\text { ranks of those of } \\
\text { His friends whom } \\
\text { He has afflicted." } \\
\text { P. } 263\end{array}$ \\
\hline
\end{tabular}

In the five extracts above, El-Husseini, the novel mouthpiece for Islam, is advising and preaching his neighbors. These extracts express the writer's messages to the reader: "seek refuge from the devil," "bring a sinner to guidance," "remember God", "perform pilgrimage," and "be patient".

Arab World English Journal for Translation \& Literary Studies 
The first excerpt is from one of El-Husseini's long conversations filled with appeal and advice. The phrase الثنيطان الرجيم is a collocation, a fixed phrase stored in the minds of Egyptian people. A collocation is "the tendency of certain words to co-occur regularly in a given language" (Baker, 1992/2006, p. 47). Translating collocations is problematic because they may not have equivalents in the TL. In verse 36, Surat Al-Imrân, this collocation is interpreted as "Shaitân (Satan), the outcast," and in verse 98, Surat An-Nahl, it is rendered as "Shaitân (Satan), the outcast (the cursed one)."

In TT1, Le Gassick reduces the translation of the phrase to "the devil" ignoring the culturespecific meaning of the collocation since the word شيطان is associated with the word رجيم in the Arabic and Islamic culture. This reduction causes translation loss because it will not convey the SC to the TR. On the other hand, by using "never" instead of "Don't," Le Gassick emphasizes the

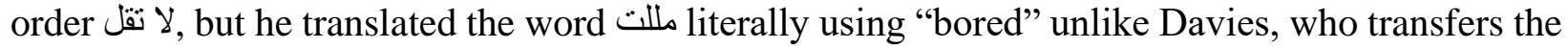
intended meaning of ملالت saying "have grown weary of this world!" reflecting the feeling of all characters in the Allay.

In the same extract, Davies uses "Lapidated" as equivalent to رجيم, but "Lapidated" means "thrown by stone." The etymology of شطن is شيطان wich means "keep away" or "distance," and رجم means "throw a stone." However, the intended meaning is symbolic: "cursed devil" or "outcast from Allah's mercy." The literal meaning by Davies violates the intertextual coherence of the skopos theory as it does not provide the required degree of communication and interaction between the ST and TR. Also, Davies' translation of استعذ باله does not achieve the intratextual coherence as the TT is not coherent. The first point of view "I" shifts to the imperative structure. "I seek refuge with God from Lapidated Satan" has changed to "say not that you have grown weary of this world!" The extract is a piece of advice, and the structure of the sentence is an imperative since El-Husseini is instructing and preaching. Despite the translation loss in TT1 and TT2, TT2 uses cultural equivalents, so the TR understand the message easily.

The ST gives the Qur'anic reference an introduction in the second extract, so both translators know that it is a verse from the Quran and hence translate it accordingly. It is the only verse with an opening in the ST, and it sums the central message of the ST: It is not in the hand of Kersha's wife nor in El-Husseini's to guide Kersha and prevent Kersha from his scandals. It is God's will to whomever He wishes. The sentence preceding the verse paves the way to this piece of wisdom. TT1 translates the extract literally by using "profligate" for فاسقالس and "sit" but TT2 conveys the meaning and culture by using "sinner." This most general equivalent communicates the cultureme, culture-specific image of فاسق. Its significance in SC is anyone who breaks a religious or moral law. Davies's use of "keep company" for يجالس. Succeeds in achieving intratextual coherence. The interpretation of verse 56, Surat Al-Qasas is "Verily, you (O Muhammad صلى الله عليه وسلم guide not whom you like, but Allâh guides whom He wills." TT2 introduces the religious allusion and transfers the skopos, coherence, and loyalty to ST and its TC.

In extract three, Davies writes the religious allusion in italic and puts it between quotation marks 'in the mention of His name the heart finds peace,' which indicates his recognition of it. However, he gives a literal translation as he conveys ذكر as "mention." The interpretation of verse 28, Surat Ar-Ra'd is "in the remembrance of Allâh do hearts find rest." Although Le Gassick uses 


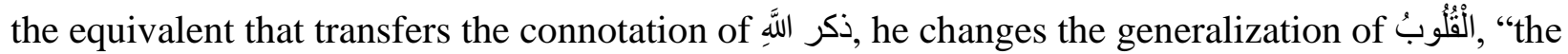
hearts" into the plural of the first-person point of view "our hearts." Using the pronoun "our" does not affect the general meaning because the translator moves within the parameters of adequacy to the ST and function and acceptability to the TL.

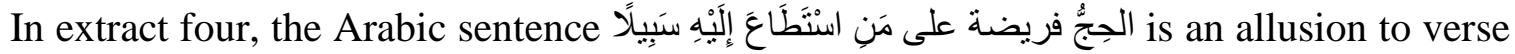
97, surat Al-Imran. Its interpretation in the Quran is "Hajj (pilgrimage to Makkah) to the House ( $k a$ 'bah) is a duty that mankind owes to Allâh, those who can afford the expenses." Davies' translation is again more proper than that of Le Gassick. Davies uses a structure and lexis understood by the TT and, at the same time, not very simple to suit the aesthetic aspect of the genre, rendering it "To make the pilgrimage is a sacred duty incumbent on any who has the means." This translation is compatible with skopos and loyalty.

The last item in the table above gives El-Husseini's previous advice. The culture-specific image of مستوصيا بالصبر is rendered effectively in TT2 as the coherence and culture are achieved. In verse 17, Surat Al-Balad, وتواصوا بالصبر is interpreted as "recommended one another to perseverance and patience." Le Gassick's translation was in 1966, and the TC at that time was different from the contemporary TC. The use of lexical equivalents, such as "Go on" for iن and "Earn as much as possible" for اسع إلى رزقا shows this difference. Also, the use of "a pious man" for المؤمن suits the time of translation more. Again Le Gassick misuses the correct article, but he conveys the whole meaning. Davies' adaptation is more feasible as it achieves its adequacy and acceptability. The use of "His friends" makes TT2 coherent as there is consistency in transferring the same expression أوليائه although Davies renders the words انهضابين literally as "Arise" and "afflicted." The paraphrasing and explanation of the situation make it understood by the TR. TT2 renders the correct meaning of the ST relying on the linguistic and cultural knowledge of the English language to preserve the intended purpose, giving culture equivalents.

\section{Conclusion}

This paper compares two English translations of Mahfouz's Midaq Allay to explore the strategies applied in translating Qur'anic verses and query the translators' loyalty to the ST. It involves the three rules of the skopos theory using Nord's model of text analysis. As a literary milestone, Mahfouz's novel marks a period of realism documenting an era of turmoil, revealing Egypt's very bleak picture of a miserable alley. Mahfouz depicts Egyptian society with its culture and ideologies. The purpose of the translations is to transfer the SC and ideologies. The first translation took place when the Arabic literature was embargoed, while the second one was after Arabic literature has received recognition in the West. The characters, including the minor and unkind ones, use verses from the Quran in their dialogues and standard talks as one of the elements of Mahfouz's style. Using allusions to the Holy Quran as a tool to criticize the social reality of people mirrors the ugly face of this society. Both the narrator and characters use verses from the Quran, so neglecting these references in translation may result in translation loss. The paper finds that both translations achieve the skopos; however, the new translation is more appropriate in terms of using cultural equivalents. Another finding is that literal translation, paraphrasing, and paraphrasing with explanations are the most common strategies. Also, the translators surrender their loyalty to the ST for the sake of the skopos. Finally, the kopos theory does not pay sufficient attention to the linguistic nature of the ST nor the reproduction of micro-level features in the TT. 
scholars should do more research on the translation of culture-specific images in Qur'anic allusions combining top-down and bottom-up approaches that consider expressive and stylistic language. * the term for a chapter of the Quran

** a "verse" of the Quran/ Ayas are verses that make up the Surahs (chapters) of the Quran, and each ayah is marked by a number.

\begin{abstract}
About the Author
Najlaa Aldeeb, a lecturer at Batterjee Medical College, has twenty years of experience in teaching ESL. She has an MTS in Translation Studies and an MA in English Language and Literature. Ms. Aldeeb is a DELTA holder whose research interest areas include literary translation, feminist literary criticism, and college writing. She has participated in national and international conferences including the $21^{\text {st }}$ International Conference on Learning, New York, USA. ID ORCid: https://orcid.org/0000-0002-6404-2741X
\end{abstract}

\title{
References
}

Al-Hilâlî, M. T., \& Khân, M. M. (1996). The noble Qur'an. Madinah: King Fahd Complex for the Printing of the Holy Qur'an.

Altoma, S. J. (2005). Modern Arabic literature in translation. London: SAQI.

Armstrong, N., \& Federici, M. (2006). Translating voices, translating regions. Rome: Aracne.

Assyyid, M. M. B. (2014). Beautiful Named of Allah. King Fahad National Library Catalogingin-Publication Data. Retrieved fro https://d1.islamhouse.com/data/en/ih_books/single2/en_The_Beautiful_Names_of_Allah. pdf

Boase-Beier, J. (2004). Knowing and not knowing: Style, intention and the translation of a Holocaust poem. Language and Literature: International Journal of stylistics, Vol. 13 (1), pp. 25-35. Retrieved from https://journals.sagepub.com/doi/abs/10.1177/0963947004039485

Baker, M., \& Saldanha, G. (eds.) (2009). Routledge encyclopedia of translation studies ( $1^{\text {st }}$ edition). London: Routledge.

Baker, M. (1992/2006). In other words: A textbook on translation. $2^{\text {nd }}$ ed. Abingdon and New York: Routledge.

Barthes, R. (2009). Mythologies. London: Vintage, Random House.

Bassnett, S., \& Lefevere, A. (1998/2000). Constructing cultures: Essays on literary translation. Clevedon: Multilingual Matters.

Cherif, A. A., Boukbout, M., Mahmoudi, M., \& Ouhmouch, A. (2011). Moroccan Arabic. Tangier: Peace Cross.

Davies, D. J. (May 29, 2011). AUC press translator Denys Johnson-Davies speaks about translating and Naguib Mahfouz. The American University in Cairo Press. Retrieved from https://www.youtube.com/watch?v=JG0eyQd31aQ\&feature=emb_rel_pause

Davies, D. J. (2006). Memories in translation: A life between the lines of Arabic literature. Cairo: The American University in Cairo Press.

Jaffer, A., \& Jaffer, M. (2009). An introduction to Quranic sciences. London: ICAS press. 
Ku, M. (2006). La traduccion de los elementos lingüísticos culturales (chino-espanol). Estudio de Sueno en las Estancia Rojas. PhD diss. Universitat Autonoma de Barcelona.

Lennon, P. (2004). The function of allusion: Allusion in the press. Retrieved from https://www.questia.com/library/118908896/allusions-in-the-press-anappliedlinguistic-study

Leppihalme, R. (1997). Culture bumps: An empirical approach to the translation of allusions. Retrieved from http://www.multilingual-matters.com/display.asp?K=9781853593734

Mahfouz, N. (1947): Ziqaq Al Midaq. Cairo: Dar al-Shorouk.

Mahfouz, N. (1966). Midaq Alley, Translated by Le Gassick, T. New York: Quality Paperback Book Club.

Mahfouz. N. (2011). Midaq Alley, Translated by Davies. H. Cairo: The American University in Cairo Press.

Moramollu, G. (2016). Ideology and literature. Humanities and Social Sciences Review. 6 (1), pp. 455-460. Retrieved from file:///Users/mac/Downloads/V6Z507 humanitiesARTCLEPUBLSHEDIDEOLOGYANDLITARETURE.pdf

Munday, J. (2008/2016). Introducing translation studies: Theories and applications. $2^{\text {nd }}$ ed. Oxon: Routledge.

Newmark, P. (1988). A Textbook of Translation. Hemel Hempstead: Prentice Hall.

Nord, C. (2018). Translating as a purposeful activity: Functionalist approaches explained ( $2^{\text {nd }}$ ed.). London:Routledge.

Nord, C. (2005). Text analysis in translation: Theory, methodology, and didactic application of a model for translation-oriented text analysis, translated by Nord, C., \& Soarrow, P. ( $2^{\text {nd }}$ ed.). Amsterdam: Rodopi.

Nord, C. (1997). Translating as a purposeful activity: Functionalist approaches explained. Manchester: St. Jerome Publishing.

Reiss, K. (1971/2000). Translation criticism: Potential and limitations. Translated by Rhodes, E. F. Manchester: St Jerome and American Bible Society.

Rushdy, N. (1997). Methods of rendering the story of Moses in the Holy Qur'an: An analysis of three translations. Unpublished PhD. Thesis. Cairo: Cairo University.

Said, E. (1999, September 17). Embargoed literature. The Nation, pp. 278-80. Retrieved from file:///Users/mac/Downloads/Embargoed\%20Literature.pdf

Vermeer, H. J. (1987). What does it mean to translate? Indian Journal of Applied Linguistics. 132, 25-33. Retrieved from https://booksc.xyz/s/?q=Varmeer+What+does+it+mean+to+translate\%3F

Wong, D., \& Shen, D. (1999). Factors influencing the process of translating. Meta, 44 (1), pp. 78-100. Retrieved on September 27, 2019, from https://doi.org/10.7202/004616ar 